\title{
DISCOURSE AND AUTHORITY IN EUROPEAN AND POST-COMMUNIST LEGAL CULTURE
}

\author{
Siniša Rodin*
}

Summary: Based on Paul Feyerabend's distinction between guided and free exchange, the author argues that the accession of the post-communist states to the European Union took the form of the former kind, i.e. the form of communication where all participants in the process voluntarily embrace the meaning of law developed through inter-institutional discourse within the European Union. However, due to the nature of European law which does not apply to the purely internal situations in the Member States, a completely guided exchange between the EU and candidate countries is not possible. The author holds that the unity of, and loyalty towards, the European constitutional framework in an enlarged European Union is best served by the discoursive construction of the meaning of constitutional choices, principles and rules.

As stated in Article 1 of the Treaty of Nice, the Treaty "... marks a new stage in the process of creating an ever closer union among the peoples of Europe, in which decisions are taken as openly as possible and as closely as possible to the citizen". ${ }^{1}$ Weiler qualified this visionary commitment when he observed that "No matter how close the Union, it is to remain a union among distinct peoples, distinct political identities, distinct political communities".2 Indeed, as in any non-unitary structure based on pluralism, those who interpret law are by necessity confronted with disagreement over competing definitions of basic constitutional concepts, such as what is good, equal or just. ${ }^{3}$ The peoples and polities of Europe, being different from each other, contribute to the construction of the common meaning of European law, the legal order, and ultimately the Constitution. Their individual understandings are communicated among qualified audiences across Europe and are attributed meaning. Law, including a constitution, lives through interpretation - the assignment of meaning to words written on paper. To have a say means to have power. ${ }^{4}$ Yet, the starting positions of the actors from the old and new Member States of the EU contributing to the constitutional discourse are

\section{. Professor of Law, Department of European Public Law, University of Zagreb, Faculty of Law}

${ }^{1}$ The Preamble to one of the early versions of the Draft Treaty Establishing a Constitution for Europe specified: "The peoples of Europe, in creating an ever closer union among them, are resolved to share a peaceful future based on common values." Provisional consolidated version of the draft Treaty establishing a Constitution for Europe, Brussels, 25 June 2004 (OR. fr) CIG 86/04. The final version was changed and reads: "Convinced that, thus 'United in diversity', Europe offers them the best chance of pursuing, with due regard for the rights of each individual and in awareness of their responsibilities towards future generations and the Earth, the great venture which makes of it a special area of human hope", OJ C 310 of December 16, 2004.

2 J. H. H. Weiler, Federalism and Constitutionalism: Europe's Sonderweg, Harvard Jean Monnet Working Paper No. 10/2000, also in Kalypso Nicolaidis and Robert Howse (eds.), The Federal Vision: Legitimacy and Levels of Governance in the US and the EU (2001) Oxford: Oxford University Press,

${ }^{3}$ This led Rosenfeld to propose that legal interpretation in pluralist societies is in crisis. Michel Rosenfeld, Pragmatism, Pluralism and Legal Interpretation: Posner's and Rorty's Justice without Metaphysics Meets Hate Speech (1996-1997) 18 Cardozo L. Rev. 97; See also Günther Teubner, De Collisione Discursuum: Communicative Rationalities in Law, Morality and Politics(1995-1996) 17 Cardozo L. Rev. 901. Teubner draws attention to the "... fragmentation of universal rationality into a disturbing multiplicity of discourses." At p. 901.

4 “Das Sagen-haben bedeutet Macht haben.” Paul Kirchof, Recht wirkt durch Sprache(2004) Festschrift für Erik Jayme, Band 2, p. 1167, Selier, Munich. 
different in terms of legal and political culture - while one is of democratic pluralism, the other was dominated by the ideology of the communist era. ${ }^{5}$ The legitimacy of any democratic legal order requires a broad agreement that goes beyond mere compliance. ${ }^{6}$ So too does the European one. Such an agreement must be reached by assigning meaning to basic notions that define the political or legal culture, and it is built in interaction between different actors.

I am setting off from a realist position, claiming that reality is constructed and construed socially, through interaction, and that social construction of reality depends on the intensity of power that is delivered to the debate by each respective participant. It seems to me that in a Europe of 25 and more members, the fundamental semantic building blocks of the European constitution will necessarily continue to reflect the positions crystallised so far by traditional actors, but will not necessarily be identical to those positions. Namely, the discoursive and procedural nature of European constitutionalism by necessity allows the elements of political and legal heritage that still persist in the legal and political culture of the new Member States to contribute to the definition of the European Constitution. ${ }^{7}$

In this paper I will first give some thought to the pluralist-realist ${ }^{8}$ count in an attempt to explain how political and/or legal reality depend on a qualified agreement between the participants in discourse. ${ }^{9}$ I will further proceed by highlighting some fundamental differences in the understanding of constitutionalism and law in the former communist as opposed to the long-time liberal democratic Member States. These differences, I will claim, have their origin in the differing development and social function of authority and discourse in communist and liberal democratic states. In the third part, I will show how a specific understanding of the separation of powers in the legal and political culture of post-communist states restricts rational discourse and excludes the judicial branch. In the fourth part, I will present certain elements of post-communist legal culture that, in my opinion, create obstacles for the acceptance of rational discourse. Finally, I will argue that the unity of and loyalty to the European constitutional framework, in the European Union of 25 or more Member States, can be secured only by the discoursive construction of the meaning of constitutional choices, principles and rules.

\section{I.}

Legal pluralism is understood as one of the underlying concepts of post-modern legal scholarship. According to the pluralist proposition, no one can claim privileged access to the truth of constitutional or legislative matters within the institutional framework of democracy. This understanding breaks down with the traditional Kelsenian understanding of a legal system as a hierarchy of legal rules, and introduces a "... conception of different legal spaces superposed, interpenetrated and mixed in our minds...". ${ }^{10}$ In methodological terms, legal pluralism marks a departure from understanding a legal order exclusively as an objective

${ }^{5}$ Sometimes there is little agreement on both libertarian and egalitarian ideas even among old Member States, which is demonstrated by their widely diverging social policies and agendas.

${ }^{6}$ Jürgen Habermas, On Law and Disagreement. Some Comments on "Interpretative Pluralism, (June 2003) 16 Ratio Juris 2 p. 187. Habermas speaks about the legitimacy of a democratic order. I hold that the same counts for a legal order.

${ }^{7}$ It is popular to say that the Moon revolves around the Earth. However, the fact is that both the Moon and Earth revolve around a common centre of gravity.

${ }^{8}$ Habermas, see n. 6 at p. 189. Realism proposes that reality (truth) is socially construed under the influence of the most authoritative actors. social facts.

${ }^{9}$ Qualified agreement is an agreement of parties concerned to agree about a certain interpretation of 
reality, claims that objective reality itself is construed subjectively, ${ }^{11}$ and proposes a subjective approach according to which law amounts to an outcome of "cognitive fermentation" that takes place at the individual level and influences law-making through discourse. As much as legal order defines individual action, it is individual action which, by communication, defines the legal order. ${ }^{12}$ In such circumstances the meaning of law depends not on an ultimate and undisputed authority, for example "the command of the sovereign", as proposed by John Austin, ${ }^{13}$ but on the outcome of the discoursive process, an outcome which is itself subject to permanent re-interpretation.

Realism, on the other hand, proposes that reality (truth) exists outside and beyond individual convictions and understandings and is socially construed under the influence of the most authoritative actors. Accordingly, reality depends on the discoursive inputs of participants having different social "weight". Confronted with reality, individual interest is best served by adjusting action to predictions of what the law is. ${ }^{14}$ Stated briefly, the pluralistrealist position assumes that:

- law is defined not by the letter of the law, but by its meaning;

- the definition of what the law is (the meaning of law) is a function of the interaction between multiple actors;

- the discoursive definition of law results in the "politicisation" of law by bringing regulatory purposes and policies into legal analysis;

- participants in the discourse have different strengths and faculties to contribute to the definition of law;

- once defined, law is subject to permanent re-interpretation through legal and social discourse.

European constitutionalism has been growing out of rational discourse which, as suggested by Robert Alexy, assumes that conditions of communication prevent irrational termination of argumentation, secure freedom of choice of topics and equal conditions for participants, and exclude coercion. ${ }^{15}$ In circumstances of such rational discourse, a broad and qualified consensus of discourse participants is intermittently reached on the meaning of legal rules, principles or legal concepts. Due to general agreement about their meaning, such rules,

${ }^{10}$ Boaventura de Sousa Santos, Law: A Map of Misreading. Toward a Postmodern Conception of Law (1987) 14 J. L. \& Soc'y 279,293.

${ }^{11}$ Paul Feyerabend, ERKenNTnis Für FReIE Menschen (1979) Frankfurt, Suhrkamp Verlag.

${ }^{12}$ As Teubner put it, "Legal pluralism is then defined no longer as a set of conflicting social norms in a given social field, but as a multiplicity of diverse communicative processes that observe social action under the binary code of legal/illegal." Günther Teubner, The Two Faces of Janus: Rethinking Legal Pluralism (19911992) 13 Cardozo L. Rev. 1443, 1451.

${ }^{13}$ John Austin, The Province of Jurisprudence Determined, $1^{\text {st }}$ edition, Cambridge, 1832.

${ }^{14}$ According to Holmes, law is a “...prediction of incidence of public force through the instrumentality of the courts...". Oliver Wendell Holmes, The Path of Law, (1996-1997) 110 Harv. LR 991.

${ }^{15}$ R. Alexy, A Theory of Legal Argumentation (1989) R. Adler and N. MacCormick (trans.), Oxford. As Habermas encapsulated, "In rational discourse, we assume that conditions of communication obtain that (1) prevent a rationally unmotivated termination of argumentation, (2) secure both freedom in choice of topics and inclusion of the best information and reasons through universal and equal access to, as well as equal and symmetrical participation in, argumentation, and (3) exclude every kind of coercion - whether originating outside the process of reaching understanding or within it...”, Jürgen Habermas, Between Facts And Norms: Contributions to a Discourse Theory of Law and Democracy (1996) Polity Press, Cambridge, at p. 230. 
principles or concepts become difficult to re-define and thus become constitutionalised landmarks of a given legal system. Such landmarks are sometimes enacted by pouvoir constituant, sometimes merely internalised by the discourse participants, and sometimes by both. ${ }^{16}$ So has the Constitutional Treaty ${ }^{17}$ been developed from a complex web of extended communication in which definitions were made and agreed to. Finally, those definitions were solemnised in the final act of signing and in the expected ratification by all Member States.

Examples of constitutional developments so described are many, just to mention the constitutional principles of the direct effect and supremacy of Community law, principles of the four freedoms, fundamental rights, etc. The development of the gender equality law in the European Union provides a good example of pluralist-realist assumptions at work.

The original text of Art. 119 of the Treaty Establishing the European Economic Community laid down an obligation for each Member State to ensure that the principle of equal pay for male and female workers for equal work is applied. This simple provision developed into an area of law covering a wide range of individual rights, policies and social choices pursued by the Community and its Member States. As stated by the ECJ in the Defrenne II case,

"... it is impossible not to recognise that the complete implementation of the aim pursued by Article 119, by means of the elimination of all discrimination, direct or indirect, between men and women workers, not only as regards individual undertakings but also entire branches of industry and even of the economic system as a whole, may in certain cases involve the elaboration of criteria whose implementation necessitates the taking of appropriate measures at community and national level."18

By making the equal pay provision a component of Community social policy, the ECJ legitimised a wide range of actors to participate in the law-making process. Furthermore, attempts to affect development of law by test cases contributed to the development of the meaning of the "equal pay" concept. When the Equal Treatment Directive was passed in $1976,{ }^{19}$ it became clear that the meaning of equality reaches far beyond the concept of equal pay and embraces the principle of equal opportunities for men and women. The principle was subsequently constitutionalised by the Amsterdam Treaty, and further developed by the ECJ notably in the landmark Kalanke ${ }^{20}$ and Marschall ${ }^{21}$ cases. Both cases came to the ECJ as requests for a preliminary ruling from German courts which were in active dialogue both with national legislatures (the parliaments of the respective Länder) and the ECJ. The meaning of the equal opportunities concept $t^{22}$ which emerged from the discourse was a result of dialogue between national legislative authorities, national courts, the ECJ, the legislative institutions of the EU, notably the Parliament and the Council, and not least importantly, individuals and

${ }^{16}$ As Rosenfeld has put it, “...so long as the consensus holds, there may be no awareness of prevailing philosophical inconsistencies and no need to fill existing theoretical gaps." Rosenfeld, see n. 4 at p. 108.

17 Treaty establishing a Constitution for Europe, O.J. C 310 of December 16, 2004.

${ }^{18}$ Case 43/75, Gabrielle Defrenne v Société anonyme belge de navigation aérienne Sabena, [1976] ECR 455.

${ }^{19}$ Council Directive 76/207/EEC of 9 February 1976 on the implementation of the principle of equal treatment for men and women as regards access to employment, vocational training and promotion, and working conditions O.J. L 039 of 14/02/1976 at pp. 40-42.

${ }^{20}$ Case C-450/93, Eckhard Kalanke v. Freie Hansestadt Bremen [1995] ECR I-3051.

${ }^{21}$ Case C-409/95, Hellmut Marschall v. Land Nordrhein-Westfalen, [1997] ECR I-6363.

${ }^{22}$ That women as qualified as men may be accorded priority in employment, albeit not automatically and mechanically, but subject to a "saving clause". 
NGOs. Each of them participated within their respective position of authority, bringing in different political and legal angles. The aforementioned dialogue brought into play a number of other concepts, whether broad, such as gender mainstreaming, empowerment and affirmative action, or technical, such as "the saving clause". Each of these concepts enriched the discourse and streamlined the meaning of the equal opportunities principle. Finally, these concepts stabilised in time and gained wide recognition. Their constitutional significance is entrenched in the expectations of individuals that authority created in pluralist discourse will be enforced.

To emphasise once again, the authority of constitutional principles, such as gender equality in the EU, was created by and owes its legitimacy to a qualified discourse ${ }^{23}$ in which the participation of widely legitimised actors was ensured.$^{24}$ Finally, language is created as a methodological tool that facilitates the discourse and expresses our human self ${ }^{25}$ in the relevant field. Such authority created in discourse, and for the purposes of this paper we can call it discoursive authority, rests on expectations that enforcement of the underlying qualified agreement will be based on values and oriented towards ends that are universally acceptable, ${ }^{26}$ without having to waste time on resolving conflicts between formalistic, scientific or logical artifices.

II.

While the above-mentioned pluralist-realist assumptions are very well established in Europe's west, and even described as banal on the other side of Atlantic, ${ }^{27}$ they have little practical, theoretical or cultural underpinning in post-communist Europe. Political realities that defined fundamental concepts such as constitutionalism, the rule of law, equality or fundamental rights, created an entirely different language in which the meaning of rules was determined by the authority of naked power in the absence of rational discourse as understood by Alexy. Instead of rational discourse that shaped the legal and institutional landscape of Europe's west, the predominant discourse in Central and Eastern Europe was authoritarian. ${ }^{28}$

${ }^{23}$ It is easy to agree with Habermas that sound procedures guarantee “... the certainty of law at a different level. Procedural rights guarantee each legal person the claim to a fair procedure that in turn guarantees not certainty of outcome but a discursive clarification of the pertinent facts and legal questions.", see n. 15 at p. 220; See also, Hugh Baxter, Habermas's Discourse Theory of Law and Democracy (2002) 50 Buff. L. Rev. 205, 302.

${ }^{24}$ While institutional discourse primarily means a discourse between institutions, separate discourses take place within each of them. In that sense, national judges, parties to the proceedings, Advocates General, participate in intra-institutional discourse.

${ }^{25}$ Richard Rorty, Consequences of Pragmatism (1982), at xxxvii, quoted from Rosenfeld, see n. 4. at p. 126.

${ }^{26}$ For Habermas values are teleological and reflect intersubjectively shared preferences. Habermas, see n. 15 . at p. 255 .

${ }^{27}$ See Richard Rorty, The Banality of Pragmatism and the Poetry of Justice (1989-1990) 63 So. Cal. L Rev. 1811, at p. 1812: "Even under this broader definition of formalism, however, it is not so easy to find a good example of a formalist among legal theorists"; Thomas Grey, Holmes and Legal Pragmatism (1989) 41 Stan. L. Rev. 787, 814.

28 The phenomenon of authoritarian discourse results partly from communist ideology and partly from decades-long exclusion from mainstream legal discourse. Nevertheless, due to its deductive nature it has managed to persist, at least for a limited time in an ideology-free environment. Paradoxically, unconditional acceptance of the acquis communautaire as a take-it-or-leave-it deal in membership negotiations by definition excludes discourse. See, for example, Wojciech Sadurski, Accession's Democracy Dividend: The Impact of the EU Enlargement upon Democracy in New Member States of Central and Eastern Europe (2004) 10 ELJ, 4 , p. 371, 382. In other words, the meaning of legal rules that has been developed gradually and over the years in the EU is being served to candidate countries on the silver platter of authority. Ćapeta holds that legal formalism will 
The main characteristic of such authoritarian discourse is the proclamation and imposition of one truth as universal and final. Such discourse was authoritarian since it purported to have a social monopoly over determining the meaning of legal and political language at the top of the political hierarchy and communicating it downward. It was, nevertheless, a discourse, since communication of meaning defined in an authoritarian way was indispensable to support the claim of universal acceptance, the maintenance of which is a condition of the system's integrity.

The malicious nature of the authoritarian discourse is properly demonstrated by a drastic example presented by Imre Lakatos: "In 1949 the Central Committee of the Soviet Communist Party discussed the merits of Mendelian genetics as opposed to Lysenko's environmentalist theory. They decided that Lysenko's theory was better and the leading authority of the rival school, N. I. Vavilov, was killed in a concentration camp." 29

Certainly, while authority generated in rational discourse is necessarily inductive and inclusive, making the creation of new categories possible, the model of authoritarian discourse is deductive, based on definitions that may or may not correspond to reality, and transmits them to the lower levels of a social or professional hierarchy.

In the post-communist countries of Eastern Europe, deductive transmission of the prescribed meaning was, and to a large degree still is, present in all spheres of life: legislation, adjudication, legal scholarship, education. Government is understood as a mere transmission of the parliamentary will, ${ }^{30}$ and the function of adjudication is understood as "applying the law" and not as settlement of disputes between parties. ${ }^{31}$ Legal scholarship was not expected to be critical but descriptive and apologetic, while the function of education was understood as transmission of the uncontested ultimate truth from teachers to disciples: magister dixit, discipulus scripsit. Ultimately, the "objectivity" of the legal system defined during times of communism gradually developed into the dominant legal culture that members of the legal profession did not realise at all since they saw it as universal. ${ }^{32}$ That development was facilitated by an understanding of law as an autonomous science, and an understanding of the task of jurists, both practitioners and legal theorists, as finding the "right answers" for all legal questions exclusively within the legal system, regardless of social reality.

The language of law and legal concepts that were developed under conditions of authoritarian discourse did not miraculously disappear with the fall of the Berlin wall. They outlasted communist ideology, corroborating what Max Planck wrote in his Scientific Autobiography, that new scientific truth does not triumph by convincing its opponents and making them see the light, but rather because its opponents eventually die, and a new generation grows up that is familiar with it.

Against the backdrop of this legal culture, the post-communist states of Central and Eastern Europe embarked upon the process of accession to the European Union, some of them

actually help judges in new and prospective Member States in applying Community Law. See Tamara Ćapeta, Preparing New European Judges: The Case of Croatia, unpublished.

${ }^{29}$ Imre Lacatos in Matteo Motterlini (ed.), For and Against Method, Imre Lakatos and Paul Feyerabend (1999) University of Chicago Press, Chicago, at p. 21.

${ }^{30}$ In former Yugoslavia, the government was officially called the "Federal Executive Council".

${ }^{31}$ In fact, an ideological given was that socialist society knows no disputes which exist only between social classes in bourgeois societies.

32 Iris Marion Young, Justice and the Politics of Difference (1990) Princeton University Press, Princeton. 
completing it on May 1, 2004. As far as harmonisation of law is concerned, post-communist legal orders confronted two problems.

The first problem refers to the difference between the nature and complexity of postcommunist and liberal democratic societies that emerged as a result of different dynamics in the development of their respective economies and societies in the first half of the twentieth century. Therefore, the complete reception of law developed through rational discourse which would go beyond mere transcription of legal rules does not seem to be possible in authoritarian societies. It is easy to agree with Eugen Ehrlich that if the two societies differed as widely as, say, the original societies of uncivilized and semi-civilized peoples, or the Bolshevist societies of modern civilised peoples, then a similar transfer of Legal Provisions would have been utterly impossible. ${ }^{33}$

The second problem of harmonisation of law emerges after the social and economic substance subject to legal regulation is sufficiently developed, that is, after the reception of law becomes meaningful. Confronted with the obligation of integrating and applying the legal rules developed in a system defined by rational discourse, such as the legal system of the European Union, post-communist jurists are faced with the problem of adjusting the language of law and the meaning of legal concepts to the pluralistic discoursive paradigm. Therefore, the process of harmonisation must not be understood merely as an exercise in the alignment of the legal rules of national law with the legal rules of Community law. Even in instances of literal transcription, these rules acquire a different meaning and are applied differently by the courts. In other words, since knowledge (knowledge of law included) is context sensitive, legal rules necessarily have a different meaning in different knowledge standard contexts. ${ }^{34} \mathrm{I}$ use the term semantic dissonance for this difference in the understanding of fundamental legal and political concepts.

This means that elements of normative language cannot be expected to have a standard meaning in every Member State. Even among the "old" Member States, there exist opposing understandings and value ascriptions for certain fundamental concepts, such as federalism. However, the phenomenon of semantic dissonance is even more apparent when postcommunist societies enter the discourse. Namely, where applied, the model of authoritarian discourse, being inherently deductive, does not hold new knowledge ascriptions as legitimate, rather it treats them as exceptions, and does not permit normative language to have any other meaning than standard, which is, to reiterate, determined at the top. Needless to say, the meaning of fundamental legal concepts, such as the right to life, liberty or property in Europe's East and West differed dramatically. Moreover, the public order, as understood by the dominant legal culture, radiated through the entire legal system, adversely affecting the exercise and even the mere recognition of individual rights. Those were understood as secondary and submerged beneath the "general" interest.

III.

Examples of semantic dissonance are sometimes striking. For instance, the rule of law, or the Rechtstaat principle, is understood not as government limited by law, but as naked state power to enforce laws, even in the face of violations of fundamental rights. One of the drastic examples of such understanding is the oft-repeated (since the late 1980s) statement of

\footnotetext{
${ }^{33}$ Eugen Ehrlich, The Sociology of Law (1922-1923) 36 Harv. LR 129, 143.

${ }^{34}$ Thomas Hofweber, Contextualism and the Meaning-Intention Problem, in Cognition, Agency AND Rationality, edited by K. Korta, E. Sosa and J. Arrozola, Kluwer, 1999.
} 
Slobodan Milošević, that public protests of the Albanian population must be crushed by means of the Rechtstaat ("sredstvima pravne države"), meaning by naked police force.

The readiness of the judiciary to apply the constitution directly can be taken as one of the indicators of self-understanding and the role of the judicial branch within a constitutional framework. In post-communist societies, the crucial question is whether the constitution is understood as a legal instrument and applied by the courts, or as a mere political declaration. As noted by Gabriel Andreescu, Romanian judges apply the Constitution reluctantly. "In the absence of an express article allowing the rights provided for by the Constitution to be directly enforced, the Romanian courts are extremely reluctant to consider them as such and have always asked for ordinary laws to include and develop such provisions with procedural terms. ${ }^{35}$ Criticism of such an understanding is emerging only slowly ${ }^{36}$ primarily among legal scholars, and rarely among practitioners. Nevertheless, denial of the legal nature of the Constitution can still be found in law-school textbooks. ${ }^{37}$ As a consequence, courts and public administration rarely apply the Constitution directly, if at all, ${ }^{38}$ and it cannot be explained by the self-referential nature of statutes ${ }^{39}$ but by the dominance of a regulatory state relying on sub-regulation which is often arbitrary and disempowering. Even the concept of individual public rights (subjektive öffentliche Rechte) as defence against the state is not conceptualised. The Constitutional Court protects individual rights in constitutional appeal procedures, but ordinary courts rarely do so, if at all. In Croatia, ordinary courts have the power to stay proceedings and to institute constitutional review of legislation if they have to apply constitutionally suspect legislation. However, since the Constitutional Act on the Constitutional Court was enacted in 1991, there have been no instances of such review. A recent example of the ignorance of ordinary courts is related to the amendment of rules related to family violence. Due to a restructuring of legislation, family violence is no longer incriminated by Article 362 of the Family $\mathrm{Act}^{40}$ but by the Protection Against Family Violence Act. ${ }^{41}$ Due to a technical error, there was a one week gap between the effective dates of the two laws, creating a period during which family violence was not a crime at all. This resulted in a massive dismissal of cases (more than 2000 cases), rationalised by the principle of nullum crimen sine lege. Not a single court has ever instituted the constitutional review procedure in order to challenge this obvious error on constitutional grounds.

${ }^{35}$ Gabriel Andreescu, Right-Wing Extremism in Romania (2003) Cluj, at p. 56.

36 Tamara Ćapeta, Preparing New European Judges: The Case of Croatia, unpublished. Similar arguments were presented by Branko Smerdel at the annual conference of the Croatian Judges Association, Zagreb, July 2004.

${ }^{37}$ For example, Ivo Borković, Upravno pravo ( 1997) $8^{\text {th }}$ edition, Informator, Zagreb, at pp. 59, 90, 91. Borković maintains through eight editions of his standard textbook of administrative law that the Constitution provides for a set of abstract principles that have to be concretised by (sic!) administrative law.

${ }^{38}$ For example, in case No. II Kž-888/03-3 of January 07 2004, the Supreme Court stressed that Croatian courts have an obligation to apply statutes, regardless of whether the concrete legal basis for detention is harmonised with international treaties or the Constitution. The Supreme Court did not even attempt to apply constitutional or international standards directly. "The objections of the defence aimed critically at provisions of the Criminal Procedure Act, particularly concerning the said legal basis for detention, in respect of international treaties and the Constitution, are not founded. Courts in the Republic of Croatia have an obligation to abide by positive rules of law, and the validity of this legal basis for detention specified by the Criminal Procedure Act cannot be brought into question" (author's translation).

${ }^{39}$ Daniela Caruso, The Missing View of the Cathedral: The Private Law Paradigm of European Legal Integration (1997) 3 ELJ 3, quoted from Martijn W. Hesselink, The New European Legal Culture (2001) Nijhoff, , fn. 10 at p. 11.

\footnotetext{
${ }^{40}$ Narodne novine, No. 162/1998 as amended, Narodne novine, No. 116/2003.

${ }^{41}$ Narodne novine, No. 116/2003.
} 
The reluctance of the courts to apply the Constitution directly can be explained by post-communist inertia and the persistence of the concept of unity of powers which used to be one of the dominant dogmas of the communist era, according to which all power is vested in the national assembly which is an instrument of the dictatorship of the proletariat and its vanguard: the communist party. Accordingly, the parliament is an instrument of the "dictatorship of the working class" and the communist party, as the vanguard of the working class, has a monopoly of power and the last say in determining policy. Two sets of consequences flow from this legal heritage. First, the communist party controls the legislative process and other agencies of the unitary system of power, and second, courts are subservient to the parliament and have very little, if any, judicial discretion. The law has to be applied as written. Possible lacunae are not to be filled by methods of statutory construction, but by recourse to so-called authentic interpretation that can be obtained either from the parliament, or sometimes, the government. According to the Constitution of the Soviet Union of 1936, ius interpretandi was vested in the Presidium of the Supreme Soviet. ${ }^{42}$

Understanding of the legislature, once the assembly, today the parliament, as the dominant branch of government that controls the executive and the judiciary-now void of communist-era ideology — still persists, e.g. in parliamentary standing orders that provide for authentic interpretation of laws. It can be found in Croatia, ${ }^{43}$ Slovenia, and until recently in the Czech Republic. On the other hand, it is not present in Germany, or in the United States. ${ }^{44}$ The Croatian Parliament issued fourteen authentic interpretations ${ }^{45}$ with retroactive effect and five

${ }^{42}$ Art. 121 of the Constitution of the USSR (1936). Authentic interpretation probably originates with Justinian. Comp. Imperatoris Iustiniani Institutionum, Introduction by J. B. Moyle, D.C.L. of Lincoln's Inn, Barrister-at-Law, Fellow and Late Tutor of New College (1912) Oxford, Fifth Edition. It can be found in other legal systems, e.g. canonic law. In the law of contemporary democracies (e.g. Italy and Belgium), authentic interpretation is restricted by prohibition of retroactivity, prohibition of interference with adjudication and pending proceedings.

${ }^{43}$ Articles 176-178 of the Standing Orders of the Croatian Parliament, Narodne novine, No. 9/2001 of February 2, 2001.

${ }^{44}$ For the US, see, for example, O. W. Holmes, Theory of Interpretation (1898-1899) 12 Harv. LR 417, 420 at p. 420: "In this country, at least, for constitutional reasons, if for no other, if the same legislature that passed it should declare at a later date a statute to have a meaning which in the opinion of the court the words did not bear, I suppose that the declaratory act would have no effect upon intervening transactions unless in a place and case where retrospective legislation was allowed."

45 "Vjerodostojno tumačenje članka 23. u svezi s člankom 1. Zakona o izmjenama Krivičnog zakona Republike Hrvatske" (Narodne novine, no. 91/92.), N.n. No. 175/2004 of 13 December 2004; "Vjerodostojno tumačenje članka 3. stavka 1. Zakona o zateznim kamatama" (Narodne novine, No. 28/96) N.n. No. 58/2004 of 7 May 2004; "Vjerodostojno tumačenje članka 50. stavka 3. Zakona o sudovima" (Narodne novine, No. 3/94, 100/96, 131/97 and 129/00), N.n. No. 101/2003 of 18 June 2003; "Vjerodostojno tumačenje članka 130. Zakona o visokim učilištima", N.n. No. 78/2003 of 14 May 2003; "Vjerodostojno tumačenje članka 31. stavka 1., članka 46. stavka 1. i 2., članka 53. Stavka 4. i članka 90. stavka 1. Zakona o lokalnoj i područnoj (regionalnoj) samoupravi" Narodne novine, No. 33/01), N.n. No. 60/2001 of 4 July 2001. "Vjerodostojno tumačenje članka 2. stavka 2. Zakona o izmjenama i dopunama Zakona o sustavu državne uprave" Narodne novine, No. 48/99), N.n. No. 127/2000 of 20 December 2000; "Vjerodostojno tumačenje članka 5. Odluke o davanju ovlasti jedinicama lokalne samouprave i gradu Zagrebu za sklapanje ugovora o prodaji nacionaliziranih i konfisciranih stanova", N.n. No. 119/2000, of 29 November 2000; "Vjerodostojno tumačenje članka 12. stavka 3. Zakona o izborima zastupnika u Hrvatski Državni Sabor", N.n. No. 109/2000 of 7 November 2000. "Vjerodostojno tumačenje članka 6. stavka 5. i članka 27. stavka 2. Zakona o izboru članova predstavničkih tijela jedinica lokalne samouprave i jedinica lokalne uprave i samouprave, N.n. No. 64/2000 of 5 July 2000; "Vjerodostojno tumačenje članka 2., 7. i 8. Zakona o izmjenama i dopunama Zakona o trgovačkim društvima" (Narodne novine, No. 34/99), N.n. No. 121/1999 of 19 November 1999; "Vjerodostojno tumačenje članka 14. Zakona o statusu prognanika i izbjeglica" (Narodne novine, No. 96/93 and 39/95) N.n. No. 29/1999 of 26 March 1999; "Vjerodostojno tumačenje članka 1. Uredbe o potraživanjima prema poduzećima i drugim pravnim osobama s područja Republike Hrvatske oslobođenim akcijama ‘Bljesak' i ‘Oluja'”, N.n. No. 23/1999 of 9 March 1999; see also: "Ispravak Vjerodostojnog tumačenja članka 1. Uredbe o potraživanjima prema poduzećima i drugim 
decisions not to issue an authentic interpretation. ${ }^{46}$ A relatively large number of authentic interpretations and absence of concrete constitutional review indicates an understanding of the judicial branch as instrumental to the legislature. This has no constitutional underpinning but is characteristic of the dominant legal culture.

As a result of perpetuation of the concept of unity of power, the Parliament purports to strongly control not only the judicial but also the executive branch. Attempts to limit the selfexecuting character of the Stabilisation and Association Agreement ${ }^{47}$ by passing enabling legislation seeking parliamentary ratification for the effectiveness of the secondary Association $\mathrm{Act}^{48}$ and the subsequent interpellation addressed to the Government seeking a parliamentary mandate for negotiation of additional protocols to the Agreement are good examples of the understanding that, arguably quite contrary to constitutional intent, the Government does not have independent constitutional authority to act in European affairs, but has to execute the will of the legislature - formerly the Socialist Assembly, today the Parliament. ${ }^{49}$

Needless to say, this understanding of the separation of powers differs significantly from the meaning that is ascribed to this concept in the West of Europe. However, even more importantly, it is a headwind to the emerging self-awareness of the judicial branch, it suppresses discourse, de-legitimises both judges and litigants as discourse participants and locks the judiciary into the bouche de la loi role now abandoned even by French scholarship, ${ }^{50}$ sending a clear signal that courts remain instrumental and have to restrict their interpretative role. ${ }^{51}$ Certainly, under such circumstances dialogue between institutions and the discoursive creation of meaning of legal rules is not possible.

pravnim osobama s područja Republike Hrvatske oslobođenim akcijama 'Bljesak' i 'Oluja'”, N.n. No. 25/1999 of 15 March 1999; "Vjerodostojno tumačenje članka 24. Zakona o privatizaciji” (Narodne novine, No. 21/96), N.n. No. 16/1998 of 10 February 1998; "Autentično tumačenje članka 48., stavka 4. Zakona o radnim odnosima" (Narodne novine, No. 19/90. and 19/92.) Narodne novine, No. 34/1992 of 17 June 1992.

${ }^{46}$ Even decisions not to issue an authentic interpretation interpret the law in question. On such an occasion it usually specifies that the law in question does not require interpretation, as it obviously has a given (objective) meaning. See: “Odluka o nedavanju vjerodostojnog tumačenja članka 4. U vezi sa člancima 15. i 16. Zakona o izborima zastupnika u Hrvatski sabor", N.n. No.167/2003 of 22 October 2003; "Odluka o nedavanju vjerodostojnog tumačenja članka 84. stavka 1. točke 5. Zakona o lokalnoj i područnoj (regionalnoj) samoupravi”" (Narodne novine, No. 33/01 and 60/01), N.n. No. 106/2003 of 2 July 2003; "Odluka o nedavanju vjerodostojnog tumačenja članka 3. stavka 1. točke 11. i stavka 12. Zakona o komunalnom gospodarstvu", N.n. no. 150/2002 of 17 December 2002; "Odluka o nedavanju vjerodostojnog tumačenja odredbe članka 30. stavka 1. točke 3. i stavka 2. i članka 41. stavka 1. Zakona o duhanu”, N.n. no. 22/2002 of 8 March 2002; "Odluka o nedavanju vjerodostojnog tumačenja odredbe članka 50. stavka 5. i članka 67. stavka 1. točke 3. Zakona o šumama”, N.n. no. 22/2002 of 8 March 2002.

${ }^{47}$ Stabilisation and Association Agreement between the European Community and its Member States and the Republic of Croatia, Narodne novine, Međunarodni ugovori, No. 15/2001. No. $15 / 2001$.

${ }^{48}$ Zakon o provedbi Sporazuma o stabilizaciji i pridruživanju, Narodne novine, Međunarodni ugovori,

${ }^{49}$ The shift of power from the legislative to the executive branch is a well known phenomenon both in Member States and Candidate Countries. See, for example, Sadurski, see n. 28. at p. 382. Arguably, in circumstances of permissive political consensus, negotiations for membership are primarily an administrative task. Excessive legislative control over the executive can slow down the negotiating process. However, in Croatia the problem is wider and pertains to the entire understanding of the parliamentary system and allocation of constitutional powers.

${ }^{50}$ See, for example, the opinion of AG Leger in Case C-224/01 Gerhard Köbler v Republik Österreich: "Thus the national judge is no longer necessarily, as Montesquieu was able to say in earlier times, "the mouthpiece of the law'." At pt. 59 of the opinion. 
IV.

In the previous section, I have demonstrated the existence of semantic dissonance in the understanding of certain fundamental legal and political concepts that exist between postcommunist and liberal democratic European states. I have also proposed that harmonisation of national law with Community law assumes not only textual but semantic harmonisation as well. In this section I will present three main obstacles to semantic harmonisation, notably (a.) legal formalism, (b.) denial of the policy component in solving legal issues, and (c.) circular legal argumentation and reliance on sub-regulation.

(a) Legal formalism. The demise of the extreme formalism of Begriffsjurisprudenz and the limited success of reconstruction by the Freie Rechtschule that took place in Europe in the late nineteenth century ${ }^{52}$ never really occurred in Eastern Europe due to historic circumstances $^{53}$, and where it did, it came as a result of reception instead of genuine development. ${ }^{54}$ It is worth mentioning that, as a rule, the reception of law in Croatia was limited to reception of codes, and only rarely included judicial practice that had been developed. Also, during fifty years of socialist rule, original formalist assumptions, such as the objectivity, coherence and systemic nature of law degenerated into a vulgar, textual formalism, sometimes surpassing good taste. For example, one attorney invoked the principle nullum crimen sine lege, based on the fact that the name of the drug "ecstasy" was misspelled in the list of prohibited drugs. ${ }^{55}$ Examples of formalism in the Croatian legal order are abundant. For example, it is the prevailing understanding that the concept of immaterial damages includes only damages enumerated in the civil code. The consequence of such an understanding is denial of compensation to legal persons. ${ }^{56}$

(b) Denial of policy considerations. When I speak about arguments of policy, I understand them in the sense of Ronald Dworkin's definition, as arguments that "justify a political decision by showing that the decision advances or protects some collective goal of the community as a whole." ${ }^{57}$ The idea that every piece of legislation rests on a certain underlying policy originates probably from Rudolph von Jhering and is encapsulated in his famous maxim - Keine Handlung ohne Zweck ${ }^{58}$ Since the end of the nineteenth century this understanding has taken much deeper root on the American side of the Atlantic, where it fuelled the rise of American legal realism. However, even in Europe it gradually became clearer that a narrow and formalistic interpretation of law was increasingly useless in dealing

${ }^{51}$ Compare O. W. Holmes, see n. 44., at p. 420: "In this country, at least, for constitutional reasons, if for no other, if the same legislature that passed it should declare at a later date a statute to have a meaning which in the opinion of the court the words did not bear, I suppose that the declaratory act would have no effect upon intervening transactions unless in a place and case where retrospective legislation was allowed."

${ }^{52}$ See Hesselink, see n. 39. at pp. 29-32.

${ }^{53}$ In Croatia these circumstances were the First World War, the subsequent dictatorship of King Aleksandar Karađorđević, the Nazi denial of the rule of law and Josip Broz Tito's socialism.

${ }^{54}$ The impact of Begriffsjurisprudenz on judges and scholars in Russia and elsewhere in Eastern Europe is even described as enormous. See Gianmaira Ajani, By Chance and Prestige: Legal Transplants in Russia and Eastern Europe (1995) 43 Am. J Comp. L 93

${ }^{55}$ Attorney Borislav Kraljevski in Večernji list, February 15, 2004.

${ }^{56}$ Ivica Crnić, Naknada nematerijalne štete - neka pitanja, Godišnjak 17. savjetovanja Aktualnosti hrvatskog zakonodavstva i pravne prakse, Opatija, November 6-8, 2002.

${ }^{57}$ Ronald Dworkin, Hard Cases (1974-1975) 88 Harv. LR 6 1057, 1059.

${ }^{58}$ Rudolph von Jhering, Der Zweck im Recht (1904) Vierte Auflage, Leipzig. 
with complex issues of law posed by the rising interventionist state of the twentieth century. Linking legal problems with economic and social realities has re-defined the task of lawyers, and particularly of judges, in the twentieth century. This was a result of the understanding that the syllogistic structure of legal norms is meaningless from the scientific perspective, since to be valid, a conclusion must not contain anything besides what is already contained in the premises. Therefore, all fruitful scientific theories are not syllogistic, but relational. ${ }^{59}$ Briefly, legal logic became meaningless in the absence of policy considerations. As stated brilliantly by John Dewey, taking the example of the famous syllogism, ${ }^{60}$ "...the issue is not whether Socrates was mortal, the point is whether this mortality would or should occur at a specified date and in a specified way." ${ }^{\prime 1}$ To my understanding, legal analysis that ignored regulatory policies and meta-juridical, i.e. political, economic, social and other consequences is unthinkable.

The understanding that legal rules comprise a legal and policy component and that the latter is an important source of information that can be used in the interpretation of legal rules is facing two-pronged resistance in post-communist Europe. ${ }^{62}$ On the one hand, there is no substantial departure from the formalist legal tradition of the nineteenth century, while, on the other hand, denial of the policy component of law, developed as a reaction to communist intervention in the judicial process, continues even in the absence of outside pressure. Both phenomena have become part of the dominant legal culture. Combined together they created a situation in which members of the legal profession in post-communist Europe reached a broad consensus that judges should base their decisions on a strict reading of legal rules and scientific insight into the regularities of the legal system that can be comprehended and applied objectively. According to that position, answers to all legal questions can and should be found exclusively by looking to legal rules and principles. It is the role of courts, typically the supreme court, enlightened by the insights of legal science, to proclaim urbi et orbi what the law is. Commenting on non-final judicial decisions is a criminal offence, ${ }^{63}$ and incrimination is supported by the legal profession. ${ }^{64}$ Denial of the existence, not to mention

${ }^{59}$ See Matteo Motterlini (ed.), see n. 29. at p. 39.

${ }^{60}$ Socrates is a man, all men are mortal, thus Socrates is mortal.

${ }^{61}$ John Dewey, Logical Method and Law (1914-1925) 10 Cornell L. Q. 22.

${ }^{62}$ The existence of judicial policy is noted in Croatia, however with significant reservations. See, for example, the recent study of penal policy, Zakonska i sudska politika kažnjavanja u Republici Hrvatskoj, Hrvatski ljetopis za kazneno pravo i praksu, Vol 11, No. 2/2004. In the leading chapter, Professor of Criminal Law, Željko Horvatić, emphasises: "Judicial power in contemporary states that are organised according to the principle of separation of powers, does not have and cannot have any 'policy', nor can its activity be described as such when it applies law. That activity... can only refer, to a limited extent, to superficial impressions inspired mainly by aggregate statistical information that can be used only for further structural analysis, and by no means as relevant grounds for valid and credible judgement about actions of the judicial power." Željko Horvatić, "Problem odnosa u zakonu propisane i sudskim presudama primjenjene kaznenopravne represije prema počiniteljima kaznenih djela" (Zakonska i sudska kaznena politika), on pp. 381, 388-9.

${ }^{63}$ As Ćapeta noted, there is no tradition of publishing judicial decisions in full text and on a regular basis, while commenting judicial decisions that are not final is a criminal offence. Art. 309 of the Criminal Code (Narodne novine, No. 110/1997), incriminates commentary on judicial decisions that are not final subject to six months imprisonment. Tamara Ćapeta, Preparing New European Judges: The Case of Croatia, unpublished. This provision was amended in 2003, only to be more severely incriminated (Narodne novine, No. 111/2003). Although there are no officially reported cases, this 'crime' has already become a part of public discourse. See, for example, the statement of Vlado Madunić, president of the Municipal Court in Split, Slobodna Dalmacija, January 3, 2001; the statement of Aleksandra Kolarić, spokeswoman of the Croatian Government, Vjesnik, January 23, 2001. The only case reported by the local press was decided before the Municipal Court in Daruvar. The defendants - a representative of a local trade union and a journalist - were acquitted as they commented on a non-final judicial decision after the court of first instance made its decision. 
justification, of judicial policy is deeply rooted in the legal culture of the Croatian legal profession.

In addition to the denial of arguments of policy and their exclusion from legal analysis, the dominant legal culture refuses to accept the undeniable fact that judicial decisions have social consequences ${ }^{65}$ and, at least incidentally, create policy. Such an attitude makes adjudication non-transparent, the prediction of outcomes difficult ${ }^{66}$ and opens the door to undeclared policies pursued sporadically by courts ${ }^{67}$ or even individual judges.

In brief, judicial decisions are rarely informed by policy and seek justification in the text rather than in its meaning, and in its legal logic rather than in policy choices. Such an attitude renders the application of policy-oriented concepts, such as, for example, "equal opportunity" or "indirect discrimination", difficult if not impossible. ${ }^{68}$ The meaning of these and other similar concepts necessarily depends not only on the final outcome of judicial decisions - the result of judicial thinking - but also on the policy upon which these decisions are based. The textual interpretation of legal rules, so widely accepted in Croatian legal culture, creates semantic confusion and hinders the discoursive definition of meaning. Finally, hiding behind legal concepts and principles disempowers citizens in political processes. When drafting laws, the legislator attempts to achieve certain regulatory goals. Interpretation of the law that ignores these goals is counter-majoritarian, regardless of whether we are referring to judicial activism or textual formalism. Detached from the social context of a concrete case, both are equally worthless.

(c) Circular reasoning can typically be identified in judicial decisions that apply certain standards prescribed by law, without substantively underpinning their application to a pending case. For example, a case had been reported ${ }^{69}$ where the Supreme Court referred to the constitutional principle of non-retroactivity of laws, but in the same breath upheld the retroactivity of Art. 10(3) the Civil Procedure Act (Amendments), treating it as a constitutionally permissible exception. While the Constitution provides that an exception may be permissible for "specifically justified reasons", the Supreme Court did not elaborate any grounds or principles for granting an exception to the non-retroactivity rule. Accordingly, an

${ }^{64}$ The Croatian Judges Association recently called the Public Prosecutor to institute proceedings against a journalist who commented on a non-final decision of the Municipal Court in Senj, Croatia. See Jutarnji list, August 14-15, 2004.

${ }^{65}$ For example, the framework criteria for compensation of damages adopted by the Croatian Supreme Court. While these criteria provide for guidelines for compensation of a wide range of damages, they do not refer to damages incurred in sexual harassment cases. However, this is not understood by judges as a policy choice.

${ }^{66}$ Concerning lack of transparency, see Hesselink, n. 39. at p. 74.

${ }^{67}$ A good example of criminal policy formulated by a judge can be found in the criminal proceedings against Stanko Bubić, reported in Slobodna Dalmacija, March 26, 2004. The Supreme Court reversed the judgement of the County Court in Split, Croatia, confiscating the financial proceeds generated by heroin dealing from a convicted drug dealer. As the Supreme Court explained, the lower court did not take into consideration the funds invested in the purchase of heroin. Accordingly the amount to be seized was decreased by the "purchase price".

${ }^{68}$ One of the objections of the Parliamentary Committee on Legislation to the concept of indirect discrimination introduced into the Croatian legal system by the Draft Gender Equality Act was that "judges will not know how to apply it."

${ }^{69}$ Judgement of the Supreme Court No. Rev-2471/00-2 of October 07, 2003: "Although the principle of non-retroactivity of laws is proclaimed by the Constitution, the Constitution nevertheless allows for the possibility of retroactivity of individual provisions of laws in Art. 89 (5) providing that '...individual provisions of laws may have retroactive effect subject to specifically justified reasons'. This is the case with Art. 10(3) of the Civil Procedure Act (Amendments), and the objections of the plaintiff concerning prohibition of nonretroactivity are unfounded." 
exception to the non-retroactivity rule was justified because it is permissible for specifically justified reasons, and specifically justified reasons are those which are permissible. Examples of circular reasoning can also be found in legal scholarship, methodology and taxonomy. So the specific sedes materiae of administrative law is defined by the jurisdiction of administrative courts, while administrative courts have jurisdiction in administrative matters. According to this tautology, administrative law deals with administrative matters. According to the same logic, the vast part of Community law, for example competition, immigration and asylum, free movement of services, or recognition of diplomas, can be defined as administrative law, since the administrative court has jurisdiction in these matters. Finally, reliance on sub-regulation is a direct function of textual positivism. However, the problem is double-edged. On the one hand, courts prefer to look into the most concrete legal rules possible. On the other hand, the Parliament and the Government erode the authority of laws by excessive sub-regulation, sometimes reversing the higher norm. ${ }^{70}$

\section{V.}

Although many examples used in this paper originate from the Croatian experience, the scope and proportions of semantic dissonance in other post-communist states of Central and Eastern Europe ${ }^{71}$ do not seem to differ significantly. ${ }^{72}$ While examples rooted in national experiences may vary, the lowest common denominator for all post-communist countries of Eastern Europe was the absence of freedom of dialogue, the inequality of discourse participants, and state/party coercion - all being the essential constituents of the lack of rational discourse.

The absence of rational discourse in socialist legal systems led judges and other members of the legal profession to make two typical responses - concession or self-defence. Where the legal profession conceded to political bias, the result was comprehensive ideologisation of law. Recourse to self-defence resulted in the scientisation of law, hypertrophy of legal logic and recourse to legal principles and concepts. The consequences in either case are serious; however, the self-defensive reaction has proven to be far more resistant to democratic change. On the one hand, scientisation of law suppressed any empiricism in solving legal disputes and relied on legal principles and abstract, judicially developed sententiae. On the other hand, the syllogistic structure of legal rules, supported by mechanical interpretative deductionism, has prevented a pragmatic approach to solving social problems by legal methods. ${ }^{73}$

${ }^{70}$ See, for example, Government Regulation Amending the Recognition of Foreign Qualifications Act (Uredba o izmjeni zakona o priznanju inozemnih obrazovnih kvalifikacija) of December 18, 2003, Narodne novine, No. 198/2003. There are 36 Regulations adopted on the basis of "empowering legislation" based on Art. 88 of the Constitution. Such empowering legislation authorises the Government to regulate "commerce". However, the Government often uses it for other regulatory purposes, such as recognition of diplomas, regulation of misdemeanours, taxation etc. There is no explicit constitutional authorisation to amend laws. However it has become a regular practice.

${ }^{71}$ The same seems to hold for the countries Western Europe. Compare Ajani, see n. 54, fn. 70 at p. 116: "As it is known, even in countries sharing the same fundamental legal culture, identical laws, adopted as a result of legal transplant, generate in the long run different interpretations..." Such interpretations differ due to the ascription of a different meaning to them.

72 Zdenek Kühn, Application of European law in Central European candidate countries(2003) 28 ELRev. 4 551; E. Evtimov, Integration of the International Agreements into Bulgarian Law, in Andrea Ott and Kirstyn Inglis (eds.) Handbook on European Enlargement (2002) T.M.C. Asser Press, The Hague; Frank Emmert, The Independence of Judges - A Concept Often Misunderstood in Central and Eastern Europe (2002) 3 Eur. J. L. Reform 4 405; Andreescu, see n. 35. The specific situation in Croatia and other post-Yugoslav states is that certain political and legal concepts were not entirely absent from discourse. In such cases, solving semantic dissonance is more difficult then in cases of complete absence of discourse. 
Having this situation in mind, what are the consequences of Eastern enlargement for European constitutionalism, and how will semantic dissonance affect the meaning of the European constitution? As I explained earlier, instances of semantic dissonance range from a different understanding of overarching concepts, such as the rule of law, fundamental rights, separation of powers, constitutionalism, property, and liberty, to more concrete ones, such as equal pay, equal treatment, non-retroactivity of laws, proportionality, delegation of powers, discretion, state subsidies, damages, etc. Yet the entire problem of adjustment of national law to the acquis communautaire is being presented as one of harmonisation of legal rules, while the adjustment of their meaning ${ }^{74}$ is left for the future. ${ }^{75}$ Once that day arrives, the first step in resolving the problem of semantic dissonance, I believe, will require a response to the question of "how the meaning of legal rules and principles was derived".

In this respect, I maintain that the method of "getting to the meaning" in Europe's post-communist states has to go through a paradigm shift from the authoritarian to the rationally discoursive, and from the formal to the substantive in terms of legal analysis. However, even so, another problem remains. What values or criteria will be the basis for solving semantic dissonance, and what sort of interpretative theory will be necessary to accommodate legal tradition, coherence and policy in a Europe of 25 and more, without creating a system where legal certainty is replaced by a "semantic lottery"? ${ }^{76}$

There are two possible answers to these questions. First, experience shows that the post-communist societies that succeeded in becoming members of the EU voluntarily accepted a method of communication in the process of integration that Paul Feyerabend calls guided exchange. In such a form of communication, "...some or all participants adopt a well specified tradition and accept only those responses that correspond to its standards". ${ }^{77}$ The problem emerges in a situation where one side, explicitly or implicitly, refuses to accept the standards of another legal tradition and insists on free exchange, i.e. on such communication where "...the participants get immersed into each others' ways of thinking, feeling, perceiving to such an extent that their ideas, perceptions, world views may be entirely changed". ${ }^{78}$ I also find it important that, due to the nature of European law which does not apply to purely internal situations in the Member States, a complete guided exchange between the EU and candidate countries is not possible, and that one part of the interaction between the EU and its Member States will always remain in the form of free exchange.

\footnotetext{
${ }^{73}$ See Motterlini (ed.), n. 29. at p. 106
}

${ }^{74}$ Certainly there are instances of plain meaning that need no further elaboration. See, for example, O. W. Holmes, n. 45., at 420.: "I do not suppose that you could prove, for purposes of construction as distinguished from avoidance, an oral declaration or even an agreement that words in a dispositive instrument making sense as they stand should have a different meaning from the common one; for instance, that the parties to a contract orally agreed that when they wrote five hundred feet it should mean one hundred inches, or that Bunker Hill Monument should signify Old South Church."

${ }^{75}$ One of the functions of Association Agreements is semantic harmonisation. The same can be said for the process of accession negotiations. There needs to be some minimum threshold of agreement about the meaning of rules before a candidate country can accede to the EU.

${ }^{76}$ A term used by Lord Nicholls in Ghaidan v. Godin-Mendoza [2004] UKHL 30, The Times, 24 June 2004. “...a meaning which departs from the unambiguous meaning the legislation would otherwise bear ... would make... something of a semantic lottery".

\footnotetext{
${ }^{77}$ Paul Feyerabend, Science In a Free Society (1978) NLB London, at p. 29.

${ }^{78} \mathrm{Id}$.
} 
Semantic harmonisation in conditions of free exchange probably depends on whether, to paraphrase Rorty's words, Europe's constitutional reality has an intrinsic nature which we must try to discover - or are all possible descriptions of reality equally relational and extrinsic $?^{79}$ If the latter is correct, as I suspect, it is quite possible, even probable, that the meaning of law developed by jurists from post-communist countries will contribute, at least to a certain extent, to shaping the understanding of the European Constitution. I dare to propose that, in order to minimise the impact of meaning developed in authoritarian discourse, a broad agreement on ends, as Rosenfeld suggested, may obviate the need to examine or justify antiquated legal concepts and keep the focus of interpretation on workable legal solutions. In this sense, the programmatic provision envisaging an "ever closer Union" could be understood in instrumental terms as a canon of construction, meaning much more than a political declaration or wishful thinking.

${ }^{79}$ Richard Rorty, Pragmatism and Law: A Response to David Luban (1996-1997) 18 Cardozo L. Rev 75. 